\title{
MAZHAB SYAFI'I DI MALAYSIA: SEJARAH, REALITI DAN PROSPEK MASA DEPAN
}

\author{
Oleh: \\ Mahmood Zuhdi Haji Abd. Majid*
}

\begin{abstract}
Although the Shafi'ite School came later compared to any other schools of Fiqh, it was easily accepted among the people and rulers of the country. Its moderateness could have been the factor because by nature the Malays are themselves moderate in their daily practices. However, in due history, the Malays began to experience changes from time to time and became more complex and there was a feeling that not all of the Shafi'ite views could appropriately accommodate with the changes. In this process of modernization and reformation, there were those who were inclined to accept other schools of thought. Weaknesses in the traditional practices based on the Shafite Fiqh need to be overcome. Novel ideas were considered and there were some would prefer to return to the original principles of the school and manifest them in accordance with the contemporary needs and local circumstances.
\end{abstract}

* Profesor, Jabatan Fiqh \& Usul, Akademi Pengajian Islam, Universiti Malaya, Kuala Lumpur. 


\section{PENDAHULUAN}

Mazhab Syafi'i bukanlah mazhab yang pertama sampai dan tersebar di rantau ini. Mengikut kepercayaan yang berasaskan kepada tahap-tahap kedatangan Islam ke Nusantara, penyokong Syiah merupakan golongan paling awal menyebarkan pandangan mereka kepada masyarakat Islam di Nusantara. Mengikut sesetengah penulis ${ }^{1}$, kepercayaan ini berasaskan andaian sesetengah penyelidik sejarah bahawa ajaran Syi'ah pernah menguasai kerajaan Kampar di Minangkabau Timur sepanjang abad ke 11 hingga ke 13. Antara hasil peninggalan kepada penguasaan tersebut ialah peraturan pusaka yang diamalkan di bawah sistem adat Perpatih di Minangkabau sampai kepada hari ini. Sebagaimana maklum, berasaskan kepada adat tersebut keutamaan diberikan kepada kaum wanita, iaitu sesuai dengan apa yang terdapat dalam mazhab Syiah.

Bagaimanapun, tidak semua orang bersetuju dengan andaian ini. Mengikut Wan Mohd Shaghir Abdullah, andaian ini sukar dipercayai kerana tiada bukti kukuh. Pada pandangan beliau, kalau dalam bidang akidah ternyata ada bukti bahawa mazhab Syi'ah tersebar terlebih dahulu, baik secara langsung atau tidak langsung. Namun dalam bidang hukum agak sukar dipastikan pengaruhnya. Malah sebaliknya beliau merasa pasti bahawa ketika pertama masuknya Islam di Nusantara ia menurut mazhab Syafi ' $i{ }^{2}{ }^{2}$

Abdul Rahman Haji Abdullah ${ }^{3}$ juga kurang percaya dengan teori tersebut. Kata beliau, ada kemungkinan lain bahawa sistem matrilineal yang mementingkan kaum wanita ini berasal daripada warisan animisme, kerana Adat Temenggung yang menekankan sistem partilineal itu dikatakan dipengaruhi oleh undang-undang atau adat Hindu.

\footnotetext{
1 Abdul Rahman Haji Abdullah (1990), Pemikiran Umat Islam di Nusantara. Kuala Lumpur: Dewan Bahasa dan Pustaka, h. 119.

2 Wan Mohd Shaghir Abdullah (1985), Perkembangan Ilmu Fiqh dan Tokoh-Tokohnya di Asia Tenggara. Solo: Ramadhani, h. 14.

3 Abdul Rahman Haji Abdullah (1990), op.cit., h. 119.
} 


\section{SEJARAH AWAL}

Berasaskan teori atau andaian berkenaan, negeri yang paling pertama diketahui berpegang kepada mazhab Syafi'i ini ialah Samudra-Pasai. Mengikut kepercayaan itu lagi khabarnya pada mulanya kerajaan Samudra-Pasai (1042-1450) lebih cenderung kepada aliran Syi'ah. Tetapi ketika pemerintahan Merah Silu (1261-1289) seorang ulama dari Mekah yang bernama Syeikh Ismail al-Siddiq telah datang ke situ dan menukar pegangan Islam masyarakat di situ daripada Syiah kepada mazhab Syafi' ${ }^{\prime} i$. Sempena dengan penukaran tersebut nama Merah Silu juga ditukar menjadi Sultan Malik al-Salih. ${ }^{4}$ Namun mengikut sumber lain, Merah Silu sebenarnya diislamkan oleh Syeikh Ismail dan merupakan raja Samudra-Pasai yang pertama sekali memeluk agama Islam. Ini bererti bahawa mazhab Syafi'i merupakan mazhab yang paling awal diperkenalkan di Nusantara ini. ${ }^{5}$

Apa pun juga, yang jelas ialah mazhab Syafi' $i$ telah bertapak dengan kukuhnya di Nusantara sejak awal kedatangan Islam lagi. Ketika Ibn Batutah melawat Pasai pada tahun 1345, iaitu pada zaman pemerintahan Sultan Malik al-Zahir beliau dapati raja tersebut seorang yang alim dan berminat dengan soal keagamaan. Ibnu Batutah juga mendapati raja berkenaan serta rakyat baginda menganut mazhab Syafi‘i. Di Pasai juga beliau bertemu dengan dua orang ulama mazhab Syafi'i yang berasal dari Parsi. Mereka ialah Amīr Ibn Sa 'ìd al-Syirāzi dan Taj al-Dỉn al-Ișfahāni. ${ }^{6}$

Pasai pada waktu itu bukan sahaja menjadi tumpuan para pelajar daripada luar untuk mendapat ilmu, termasuk ilmu fiqh Syafi'i, bahkan tokoh-tokoh ulamanya telah pergi ke tempat-tempat lain untuk berdakwah dan mengajar. Antara tokoh ulamanya yang selalu disebut oleh para pengkaji ialah Syeikh Said Sari yang disebut sebagai orang yang mengislamkan Raja Patani, Phya

\footnotetext{
4 Abdul Rahman Haji Abdullah (1990), op.cit., h.119.

5 Ibid

6 Ibn Batutah (2003), Pengembaraan Ibnu Batutah (terj.). Kuala Lumpur: Institut Kefahaman Islam Malaysia (IKIM), h. 730.
} 
Tu Nakpa yang kemudiannya menukar namanya menjadi Sultan Islam Zillu Allah Fi al-'Alam.?

Sezaman dengan kerajaan Pasai ini ialah kerajaan Terengganu, iaitu sebuah negeri jajahan Melayu yang diperintah oleh seorang pembesar berpangkat mandulika ${ }^{8}$. Antara kesan yang masih tinggal lagi bagi kerajaan ini sampai ke hari ini ialah batu bersurat yang ditemui di Kuala Berang, Terengganu pada tahun 1898. Batu bersurat tersebut bertarikh pada 17 Rejab tahun $702 \mathrm{H}$, iaitu bersamaan dengan 22 Feb.1303. ${ }^{9}$

Dalam batu bersurat tersebut ada sepuluh "Dharma", iaitu peraturan yang cuba dilaksanakan oleh kerajaan ini. Antara peraturan tersebut ialah tentang hukum rejam atau sebat kerana berzina, mengingkari membayar hutang dan sebagainya. Berasaskan kepada apa yang tertulis di atas batu berkenaan ternyata mazhab Syafi'i menjadi asas.

Bagaimanapun, kerajaan Terengganu ini kemudiannya tumbang kerana diserang oleh kerajaan Majapahit pada abad ke 14. Dengan demikian perananya dalam mengembangkan pengajaran Islam, termasuk mazhab Syafi' $i$ terhenti. ${ }^{10}$ Begitu jugalah dengan Pasai, kerana kemudiannya kuasa politiknya menjadi lemah dan tidak berdaya lagi untuk menjadi pusat pengembangan ilmu Islam.

7 Lihat: A. Teaw \& D.K.Wyatt (1970), Hikayat Patani. The Hague: Martinus Nijhoff, hh. 71-75.

8 Istilah "mandulika" berasal daripada bahasa Sanskrit, yang bermaksud gabenor atau ketua daerah. Lihat Abdul Rahman Haji Abdullah (1990), op.cit., h. 120.

9 Lihat catatan dan huraian tentang penemuan batu bersurat ini dan hubungannya dengan tarikh kemasukan Islam di Malaysia dalam: H.S. Peterson (1924) “An Early Malay Inscription”, dalam JMBRAS, vol.11; Syed Mohd Naquib Al-Attas (1970), The Correct Date of the Terengganu Inscription. Kuala Lumpur: Muzium Negara; S.Q.Fatimi (1963), Islam Comes to Malaysia. Singapore: MSRI; Mohd. Salleh Awang (1990), Sejarah Darul Iman. Kuala Lumpur; Hamdan Hassan (1984), "Batu Bersurat Terengganu: Kajian Mengenai Isi Kandungan dan Tafsiran Bacaannya" dalam Abdullah Zakaria Ghazali (ed.), Terengganu Dahulu dan Sekarang. Kuala Lumpur: Persatuan Muzium Malaysia.

10 Lihat: S.Q.Fatimi (1963), ibid., h. 66. 
Kejatuhan Kerajaan Terengganu dan kelemahan pemerintahan Kerajaan Pasai kemudiannya telah menyebabkan pusat pengajian dan perkembangan Islam berpindah ke Melaka, iaitu di bawah naungan kerajaan Melaka (1400-1511). Di situlah mazhab Syafi‘i menyambung perkembangannya di kalangan masyarakat Islam. Antara hasil peninggalan zaman ini ialah Undang-undang Melaka ${ }^{11}$ dan undang-undang yang lahir di bawah pengaruhnya, seperti Undang-undang Pahang ${ }^{12}$ dan Undang-undang Johor. ${ }^{13}$ Sebagaimana maklum, dalam Undang-undang Melaka terdapat hukum-hukum yang berasaskan adat Melayu dan yang berasaskan hukum Islam. Begitu juga dalam Undang-Undang Pahang dan UndangUndang Johor. Bagaimanapun, yang menjadi pokok persoalan dalam tulisan ini ialah bahagian yang berasaskan hukum Islam itu. Mengikut para penyelidik ia berasaskan kepada fiqh mazhab Syafi' $i^{1}{ }^{14}$

Satu kenyataan paling tegas tentang pengaruh mazhab Syafi ‘ $i$ di Nusantara, termasuk juga di Malaysia ialah kehadiran beberapa buku utama mazhab tersebut dalam masyarakat di daerah itu. Antara buku tersebut ialah kitab Minhāj al-Ṭälibìn, karangan alImām al-Nawāwī(631-676H/ 1232 -1277). Mengikut Abdul Rahman Haji Abdullah ${ }^{15}$ buku ini mula dibawa masuk ke Nusantara melalui Pasai pada abad ke 13. Pada zaman itu Pasai dikenali sebagai pusat pengajian Islam yang penting.

11 Yang ditulis disekitar tahun 1523-1524, iaitu di zaman pemerintahan Sultan Mahmud Syah. Lihat: Armando Cortesa (1944), The Suma Oriental of Tom Pires. London: E.G.De Eredia; Liew Yock Fang (1976), Undang-Undang Melaka. The Hague: Martinus Nijhoff; R.O.Winstedt \& Josselin de Jong (1956) "The Maritime Laws of Malaka”, dalam JMBRAS ,XXIX, pt.III, h. 25-27.

12 Yang ditulis pada zaman pemerintahan Sultan Abdul Ghafar Mahaiyddin Shah yang memerintah di antara tahun 1592-1616. Lihat: R.O.Winstedt dan John E Kempe (1948), “The Malay Legal Digest", dalam JMBRAS VOL. xxi, part 1.

13 Yang dibuat pada zaman pemerintahan Sultan Mahmud al-Ghazi Ibn Abdul-Jalil Shah. Lihat: Liaw Yock Fang, op.cit, h. 37.

14 Lihat: M.B. Hooker (1984), Islamic Law in Southeast Asia. Singapore: Oxford University Press, hh. 11-13.

15 Abdul Rahman Haji Abdullah (1990), op.cit., h. 120. 
Satu buku lain ialah al-Muhadhdhab karangan al-Imām alSyirāzi (393-476H/ 1002-1083). Mengikut Abdul Rahman Haji Abdullah lagi buku ini mula diperkenalkan di Melaka di samping Minhāj al-Tălibīn yang terlebih dahulu diperkenalkan sejak zaman keagungan kerajaan Pasai lagi ${ }^{16}$.

Antara buku utama lain dalam mazhab Syafi' $i$ yang menjadi ikutan ramai masyarakat Islam di Nusantara ialah Fath al-Wahhāb karangan Abū Zakariyā al-'Anșāīi (1422-1518). Mengikut H. Mahmud Junus, buku ini pernah ditemui sebagai peninggalan ulama Minangkabau yang bernama Burhān al-Dīn. Beliau ini adalah murid kepada Abd Rauf Singkel dan yang bertanggung jawab menyebarkan fiqh Syafi'i di sana. ${ }^{17}$

Antara kitab fiqh lain dalam mazhab Syafi' $i$ yang dibawa masuk ke Nusantara ialah kitab Fath al-Mu'in', karangan seorang ulama fiqh mazhab Syafi'i yang berasal dari Malibar, India. Beliau ialah Zain al-Dín al-Malibari (m.1564), iaitu murid kepada Ibn Hajar al-Haytami (m.1566).

Sebagaimana maklum kedua-dua al-Imām al-Syỉrāzi dan alImām al-Nawawi ini merupakan dua tokoh besar mazhab Syafi' $\mathrm{i}^{18}$. Begitu juga dengan Abū Zakariyā al-'Anșarì dan Zain al-Dīn alMalibari. Mereka berdua adalah para ulama fiqh mazhab Syafi' $i$ yang terkenal di dunia Islam.

Ini bererti bahawa mazhab Syafi' $i$ telah menguasai sepenuhnya bidang pengajian hukum dan amalan mengenainya bagi seluruh Nusantara sejak dari mula kedatangan Islam lagi sehinggalah di bawah Kerajaan Melaka yang mewarisi kekuatan pemerintahan kerajaan-kerajaan Islam di Nusantara sebelum itu. Hal yang sama juga berlaku di bawah pengaruh kerajaan-kerajaan Islam di Nusantara selepas itu.

Penguasaan yang sepenuhnya ini telah menjadikan pengajian hukum berasaskan mazhab Syafi'i ini dan amalan yang berdasarkan kepada pengajarannya menjadi sinonim kepada pengajian dan

\footnotetext{
16 Ibid., h. 121.

17 H. Mahmud Junus (1971), Sejarah Islam di Minangkabau. Jakarta: al-Hidayah, h. 10.

18 Lihat: Muhammad al-Khudharī (1964), Tarīkh al-Tasyrì' al-Islāmī, c. 6. Kaherah: al-Maktabah al-Tijāriyah al-Kubrā, hh. 361-364.
} 
amalan Syariat sendiri. Dengan erti, apabila saja disebut hukum Islam, Syariat atau seumpamanya maka yang dimaksudkan tidak lain tidak bukan kecuali yang berasaskan kepada mazhab Syafi‘ i.

Selain dalam bidang pengajian dan amalan, mazhab ini juga menjadi asas kepada pembentukan birokrasi pentadbiran agama. Semua pegawai kerajaan dalam bidang keagamaan, seperti mufti, kadi, imam dan sebagainya terdiri daripada mereka yang terdidik dalam mazhab ini. Begitu juga semua undang-undang dan peraturan yang berkaitan dengan agama Islam berasaskan kepada pandangan-pandangan dalam mazhab ini.

Pendek kata, soal mazhab tidak pernah berbangkit. Kerana yang dimaksudkan dengan agama atau syariat Islam di Nusantara pada waktu itu, termasuk juga di Malaysia tidak lain tidak bukan hanyalah apa yang terdapat dalam mazhab Syafi‘i.

\section{Peringkat Kedua}

Peringkat kedua perkembangan mazhab Syafi'i di Nusantara, ialah pada zaman pemerintahan Acheh Darussalam (1205-1675). Kerajaan ini didirikan oleh Johan Syah pada tahun 1205 dan mencapai zaman kegemilangannya dalam masa pemerintahan Sultan Ali Mughayat Syah (1511-1530). Secara mudahnya bolehlah disebut bahawa kerajaan ini sebenarnya mewarisi kuasa kerajaan Melaka yang telah dikalahkan oleh Portugis pada tahun 1511. Kerana kejatuhan kerajaan Melaka pada tahun itu telah menyebabkan pedagang-pedagang berpindah ke Acheh.

Dari segi pengajian, kerajaan Acheh merupakan pusat pengajian Islam yang terpenting pada waktu itu, terutama pada abad yang ke $17 \mathrm{M}$ di mana ramai para ulama berada di situ, baik berupa anak tempatan mahupun yang datang dari luar Acheh. Mereka ini telah melahirkan ramai para murid yang kemudiannya kembali ke tempat asal masing-masing di seluruh Nusantara, termasuk di Malaysia. Oleh kerana fiqh yang mereka pelajari di Acheh ini berasaskan fiqh Syafi'i maka mereka telah membantu memperkembangkan lagi mazhab Syafi'i di seluruh Nusantara, termasuk di Malaysia.

Bagaimanapun yang ingin difokuskan dalam kertas ini ialah tentang tiga orang tokoh besar ulama Acheh pada waktu itu. Mereka ialah Nūr al-Dīn al-Rānirì, 'Abdul Rauf Singkel dan Jalāl 
al-Dīn al-Tursani. Mereka adalah tokoh-tokoh ulama yang pernah memegang jawatan Syeikh al-Islam di situ.

Nūr al-Dīn al-Rānirī menulis kitab al-Sirāt al-Mustaqīm, iaitu sebuah kitab fiqh dalam mazhab Syafi'i yang menghuraikan hukum ibadat khuusus, seperti solat, puasa, zakat dan haji. Kitab ini dianggap sebagai kitab yang pertama sekali ditulis di Nusantara, iaitu pada tahun $1634 .{ }^{19}$

'Abd al-Ra'ūf Singkel pula menulis kitabnya yang masyhur Mir'àt al-Tullāb, iaitu sebuah kitab dalam mazhab Syafi'i yang lebih lengkap daripada kitab karangan al-Rāniri. Ia tidak mengandungi huraian tentang ibadat, tetapi mengandungi huraian tentang muamalat, munakahat dan jinayat, iaitu aspek-aspek yang lebih berkaitan dengan kehidupan bermasyarakat. Tarikh penulisannya ialah pada tahun $1672 .{ }^{20}$

Sementara Jalāl al-Dīn al-Tursani pula telah menulis kitab beliau Safïnat al-Hukkām yang mengandungi hal-hal tentang muamalat, jinayat dan hal-hal yang berkait dengan pemerintahan dan pentadbiran negara. Kitab ini ditulis pada zaman pemerintahan Sultan 'Alaudin Johan Syah (1735-1760) $)^{21}$. Antara tujuan ia ditulis ialah untuk menjadi panduan kepada para hakim di Mahkamah. Kerana itu ia antara lain mengandungi bab al-Qaḍā', iaitu pengadilan. ${ }^{22}$

Selain mereka ini terdapat beberapa ulama lain lagi di Acheh pada masa itu. Antara mereka ialah Jamāl al-Dīn al-Tursānī, anak kepada Jalāl al-Dỉn. Beliau ini telah menulis kitab Hidāyat al'Awàm, iaitu sebuah kitab fiqh yang dimulakan dengan huraian "Sifat Dua Puluh". Seorang tokoh lain lagi juga bernama Jalāl al-Dīn. Beliau ini telah menulis kitab Farā'id al-Qur'àn, iaitu

19 Lihat: Zalila Sharif \& Jamilah Haji Ahmad (ed.)(1993), Sastera Melayu Tradisional. Kuala Lumpur: Dewan Bahasa dan Pustaka, h. 397.

$20 \quad$ Ibid., h. 397.

$21 \quad$ Ibid., h. 398.

22 Lihat: A Hasjmy (1982), "Naskhah-naskhah Tua Menyimpan Alam Fikiran Melayu Lama: Sebuah Studi Tentang Safinat al-Hukkam", Kertas Kerja di Simposium Kesusasteraan Melayu Tradisional, Universiti Kebangsaan Malaysia, 4-6 Nov. 
mengenai hukum pusaka. Seorang lagi ialah Muhammad Zain Ibn Jalāl al-Dīn yang menulis kitab Kasyf al-Kirām, iaitu tentang niat dan takbiratul-Ihram, juga kitab Talkhiṣ al-Falah yang menghuraikan hukum nikah dan cerai.

Dengan mengambil kira apa yang ditulis oleh 'Abd al-Ra'ūf Singkel dan Jalāl al-Dìn al-Tursani, bolehlah dikatakan bahawa pengajian fiqh Syafi'i di rantau Nusantara dan tentu sekali termasuk di Malaysia telah mencapai kemajuan setapak ke depan berbanding sebelum itu. Ini kerana kedua-dua kitab tersebut telah mengambil kira pendekatan setempat sesuai dengan tujuan penulisannya iaitu untuk menjadi panduan masyarakat termasuk para pemerintah, pentadbir dan para hakim.

Karya-karya tentang ilmu fiqh dalam mazhab Syafi'i yang dihasilkan oleh para Ulama Acheh ini telah tersebar luas ke seluruh Nusantara dan menjadi rujukan dalam tempoh yang lama. Kerana penyebaran tersebut bukan sahaja berlaku melalui jaringan pendidikan tetapi juga melalui penaklukan.

Antara negeri yang menerima pengaruh pengajian Islam, termasuk fiqh mazhab Syafi' daripada Acheh ialah Minangkabau. Sebelum ini telah disebutkan bagaimana seorang ulama yang bernama Burḥān al-Dīn, iaitu murid kepada 'Abd al-Ra' ūf Singkel merupakan tokoh yang bertanggungjawab memperkenalkan fiqh mazhab Syafi'i dari Acheh ini ke daerah berkenaan.

Sementara negeri-negeri yang menerima pengaruh Acheh melalui penaklukan pula ialah Johor pada tahun 1615, Pahang, pada tahun 1618, Kedah pada tahun1619 dan Perak pada1620. Khusus mengenai Kedah, ketika ia di bawah pemerintahan Sultan Muzafar Syah, Raja Acheh telah mengirimkan dua buah kitab kepada baginda. Kedua-dua kitab tersebut adalah hasil karangan al-Rāniri yang masing-masing berjudul al-Șirāṭ al-Mustaqìm dan Bab al-Nikāh ${ }^{23}$.

Kemudian daripada itu telah lahir tokoh-tokoh ulama tempatan di luar Acheh yang juga menulis kitab-kitab fiqh dalam mazhab Syafi'i. Antara mereka ini ialah 'Abd Malik bin Abdullah (m.1736), seorang ulama dari negeri Terengganu yang le-

23 Zulkifli Mohd Salleh (ed.)(1972), Hikayat Merong Mahawangsa, Kuala Lumpur: Dewan Bahasa dan Pustaka, h. 149. 
bih terkenal dengan gelaran "Tok Pulau Manis". Beliau pernah belajar dengan "Abdul Rauf Singkel di Acheh dan kemudian dengan Syeikh Ibrāhīm al-Kurani (1616-1690), guru 'Abdul Rauf di Mekah. Kitab karangan beliau diberi nama Risālah Naql dan Risālah Kaifyyah Niyyah. Kitab pertama mengenai bilangan yang sah bagi sembahyang jumaat mengikut qawl qadim dan qawl jadid dalam mazhab Syafi 'i. Sementara kitab keduanya ialah mengenai "niat" dalam ibadat.

Terkemudian sedikit ialah seorang tokoh besar ulama fiqh mazhab Syafi'i di negeri Banjar. Nama beliau ialah Syeikh Muhammad Arsyad al-Banjari. (1710-1812). Selepas belajar di Mekah selama 30 tahun beliau kembali ke Banjar dan kemudian menjadi mufti negeri itu pada masa pemerintahan Sultan Tahmidullah yang juga adalah sahabatnya.

Salah satu hasil penulisan beliau di bidang fiqh ialah Sabil alMuhtadīn Li al-Tafaqquh Fì Amr al-Din yang selesai ditulis pada tahun 1781. Kitab bersaiz dua jilid ini khabarnya dikarang atas arahan Sultan Banjar pada waktu itu, iaitu Sultan Tahmidullah Ibn Sultan Tamjidullah. ${ }^{24}$

Kitab ini mengandungi masalah ibadat sahaja, iaitu sama sahaja dengan kitab Nur al-Dỉn al-Rānirí, iaitu al-Ṣirāt al-Mustaqìm, malah didasarkan atas kitab tersebut. ${ }^{25}$ Namun ia boleh dianggap sebagai satu pembaharuan berbanding dengan kitab al-Sirāt alMustaqìm karangan al-Raniri itu. Kerana dalam Sabìl al-Muhtadīn ini Syeikh Arsyad telah menjelaskan berbagai-bagai persoalan hukum yang telah berlaku dalam masyarakat suku Banjar pada abad ke 18 .

Dengan lain perkataan, kitab ini telah memberi sumbangan yang bermakna kepada perkembangan pengajian fiqh Syafi'i di Nusantara kerana mengambil kira keadaan setempat yang boleh dianggap sebagai suatu perkara penting dalam memperkembang pengajian fiqh. Namun dari perspektif yang lain ia boleh disifatkan sebagai lebih mundur daripada kitab-kitab hasil karangan 'Abd alRa' ûf Singkel dan Jalāl al-Din al-Tursani kerana tidak merangkumi

\footnotetext{
24 Zalila Sharif \& Jamilah Haji Ahmad (1993), op.cit., h. 399.

25 Ibid.
} 
hal-hal yang berkait dengan mu'amalat, jinayat dan sebagainya, iaitu yang menyentuh hal-hal kemasyarakatan dan kenegaraan.

Di Patani lahir seorang ulama yang bernama Syeikh Daud bin Abdullah al-Fațani. Beliau belajar di Mekah dan lama tinggal di sana. Beliau menulis banyak buku, tetapi yang khusus tentang ilmu fiqh ialah kitab Fur $\bar{u}^{\prime}$ al-Masā'il yang merupakan sebuah kitab fiqh lengkap. Di dalamnya meliputi aspek-aspek ibadat, muamalat, munakahat, jinayat dan sebagainya. Mengikut Abdul Rahman Haji Abdullah ${ }^{26}$ buku ini, kerana sifatnya yang lengkap itu merupakan karya puncak dalam bidang fiqh di Nusantara pada waktu itu.

Selain daripada itu banyak lagi buku-buku lain yang beliau tulis, tetapi mengenai tajuk-tajuk tertentu sahaja. Antaranya ialah Munyat al-Musalli, mengenai sembahyang, Bughyat al-Tullāb yang lebih memberi perhatian kepada masalah ibadat, Ghàyat al-Taqrīb, tentang hukum fara'id dan Ị̇āḥ al-Bāb tentang hukum perkahwinan. Antara kitab-kitab beliau yang lain lagi ialah Sullam al-Mubtadi', Jawāhir al-Saniyah, Fath al-Manan dan lain-lain lagi. ${ }^{27}$

Seorang ulama lain ialah Muhammad Ibn Ismā‘īil Dawud alFațani. Antara kitab beliau yang masyhur ialah Mațla 'al-Badrāyn yang mula diterbitkan di Mekah pada tahun 1882. Sungguhpun pada permulaan kitab ini ada menyentuh tentang akidah, tetapi keseluruhannya merupakan sebuah kitab fiqh. Kitab ini bersamasama kitab Furū' al-Masā'il dan al-Sirāțal-Mustaqīm merupakan kitab-kitab fiqh yang berpengaruh di Nusantara. Selain itu ulama ini juga menulis buku-buku lain yang masyhur. Antaranya ialah al-Badr al-Wāfí Wa al-Nahr al-Șäfí dan Wasyāh al-'Irfäh Wa Asybāh al-Falāh.

Di Kelantan lahir Abd Samad bin Muhammad Saleh, yang lebih terkenal dengan gelaran Tuan Tabal (1840-1891). Antara buku yang beliau tulis ialah Kifâyat al-'Awām dan Hidāyat alTa'līm al- 'Awām.

26 Ibid., h. 138.

27 Untuk huraian selanjutnya lihat: Wan Mohd Saghir (1987), Syeikh Dawwud bin Abdullah al-Fatani Penulis Produktif di Asia Tenggara. Solo: C.V. Ramadhani. 
Selain daripada kitab-kitab yang tersebut di atas terdapat kitabkitab fiqh lain yang pernah diterbitkan di Nusantara dan telah memainkan peranan masing-masing dalam memperkembangkan pengajian Syariah secara umum dan mazhab Syafi'i secara khusus di rantau ini. Antaranya kitab Minhāj al-Salam karangan Muḥammad Zain al-Dīn Ibn Muḥammad al-Badawi al-Sambawi yang juga terkenal dengan kitabnya Sirāj al-Hudā tentang sifat dua puluh. Antara kitab lain lagi ialah Thamarat al-Muhimmah karangan Raja Ali Haji. Selain itu ialah kitab Kifâyat al-Ghulām yang ditulis oleh Ismail Minangkabau, Kifáyat al-Mubtadì oleh Muhammad Noor bin Muhammad bin Ismail al-Fatani, dan juga Kitab al-Fatāwā yang ditulis oleh Ahmad bin Muhammad Zain Ibn Mustafa al-Fatani. ${ }^{28}$

\section{SUMBER RUJUKAN}

Secara umumnya, kitab-kitab yang dipelajari di Nusantara, baik yang dibawa dari negera Arab maupun yang dihasilkan oleh para ulama tempatan semuanya bersumberkan hasil-hasil penulisan tokoh-tokoh mazhab Syafi'i zaman taqlid. Ini jelas dapat dilihat pada bahan-bahan rujukan bagi kitab-kitab fiqh yang ditulis di nusantara sendiri.

Buku al-Ṣirāt al-Mustaqīm karangan al-Rānirī, misalnya menggunakan sumber-sumber rujukan seperti Minhāj al-Tāalibìn karangan al-Imām al-Nawāwì, Minhāj al-Tullāb dan Fath alWahhāb karangan Abū Zakariyā al-Anșāì, Mukhtașar al-Fatāwā karangan Ibn Hajar al-Haitami,' 'Umdat al-Salik wa 'Uddat alNasik karangan Syahab al-Dīn Aḥmad Ibn Lu'lu' al-Nāqib dan Anwār Li A'māl al-Bararah karangan al-Ardabili.

Buku Mir'àt al-Ṭullāb karangan Abdul-Ra'ūf Singkel pula menggunakan rujukan-rujukan seperti Tuhfat al-Muhtāj karangan Ibn Hajar al-Haitami dan Nihàyat al-Muḥtāj karangan Syams alDìn al-Ramli.

28 Lihat: Wan Mohd Saghir Abdullah (1985), Perkembangan Ilmu Fiqh dan Tokoh-Tokohnya di Asia Tenggara (1). Solo: C.V. Ramadhani, hh. 114-128. 
Buku karangan Muḥammad Arsyād al-Banjarī, Sabīl alMuhtadīn menggunakan sumber-sumber rujukan seperti Minhāj al-Ṭullāb karangan Abū Zakariyā al-Anșāri, Mughni al-Muhtāj karangan Ibn al-Khātib al-Syarbinī, Tuhfat al-Muhtāi karangan al-Ramli dan kitab-kitab mazhab Syafi'i yang lain.

Kitab Furū' al-Masā'il karangan Syeikh Dawud Ibn Abdullah al-Fatani pula menggunakan sumber-sumber rujukan yang berupa kitab al-Fatāwā karangan al-Ramli dan Kasyf al-Lithām karangan Jalāl al-Dīn al-Mahallï. Sementara kitab beliau Bughyat al-Tullāb pula rujukannya ialah kitab-kitab Tuhfat al-Muhtäj karangan Ibn Ḥajar al-Haitāmí, Nihāyat al-Muhtāj karangan al-Ramli, Mughnī al-Muhtạj karangan al-Syarbīin al-Khātị, Nahj al-Wahhab oleh al-Dainurì dan Fath al-Wahhāb karangan Abū Zakariyā alAnșarì.

Manakala kitab Iḍ̄h al-Murìd, juga karangan Syeikh Dawud al-Fatani merujuk kepada kitab Minhāj al-Ṭălibīn karangan alNawāwi, dan Tuhfat al-Muhtàj oleh Ibn Hajar al-Ḥaitāmí, serta buku-buku lain lagi daripada mazhab yang sama.

Malah kitab Thamarat al-Muhimmah karangan Raja Ali Haji, walaupun dikaitkan dengan kitab Nașihat al-Mulūk dan Ihya ${ }^{\prime}$ 'Ulūm al-Dìn yang kedua-duanya karangan al-Imām al-Ghazali, juga merujuk kepada kitab Fath al-Wahhāb oleh Abū Zakariyā al-Anșari, dan Fath al-Mu 'in karangan al-Malibarí.

Semuanya ini menunjukkan bahawa pengaruh mazhab Syafi' $i$ dalam pengajian syariah di nusantara termasuk di Malaysia boleh dikatakan menyeluruh. Bagaimanapun, mazhab Syafi'i sendiri tidak diwakili dengan secara menyeluruh dalam mempengaruhi pengajian syariah di nusantara itu. Kerana tumpuan hanya diberikan kepada kitab-kitab yang ditulis pada zaman taqlid sahaja. Misalnya rujukan kepada Imam Syafi'i sendiri melalui kitab-kitab beliau seperti al-'Umm dan al-Risālah tidak dibuat.

Dari perspektif ini bolehlah disimpulkan bahawa yang dimaksudkan dengan mazhab Syafi‘i yang tersebar luas di Nusantara termasuk di Malaysia sepertimana yang dihuraikan di atas ialah sebenarnya aliran al-Nawawi dalam mazhab tersebut. Dalam mazhab Syafi'i sendiri, kitab-kitab tersebut disifatkan sebagai kitab-kitab yang mewakili zaman taqlid, iaitu zaman sesudah mazhab berkenaan berada di kemuncak perkembangan 
dan tiada apa-apa yang baru lagi untuk diterokai. Dalam keadaan seperti itu kitab-kitab seperti itu dilihat sangat berautoriti kerana dianggap sebagai kemuncak atau penghujung kepada ijtihad yang boleh dilakukan. Anjuran-anjuran supaya bertaqlid kepada mazhab Syafi' $i$ dapat dilihat dengan jelas dalam kitab-kitab UsulFiqh yang ditulis pada waktu itu. ${ }^{29}$

Keadaan seperti ini kekal berlanjutan sampai ke akhir kurun ke 19. Bagaimanapun, ini bukanlah menggambarkan kerendahan pemikiran hukum yang dianuti oleh umat Islam di Nusantara, termasuk di Malaysia pada waktu itu. Kerana walaupun pemikiran hukum yang terdapat dalam kitab-kitab tersebut dari segi idealisme pengajian syariahnya boleh dianggap statik dan tidak berkembang, tetapi berbanding dengan tahap pemikiran sebenar umat Islam di nusantara, termasuk di Malaysia pada waktu itu ia sudah cukup maju dan mendahului zaman.

Sebagaimana maklum, sebelum kedatangan Islam masyarakat nusantara sudah pun mempunyai tatacara dan nilai hidup yang tersendiri, sama ada yang berasal di situ atau yang dibawa dari luar. Namun berbanding dengan apa yang dibawa oleh Islam ia kelihatan jauh terkebelakang. Kerana itu, bagi masyarakat nusantara pada waktu itu, apa yang terdapat dalam kitab-kitab berkenaan, di samping sumber-sumber keislaman yang lain, termasuk akidah, sastera dan sebagainya sudah sangat maju. Kerana itulah mungkin mengapa Islam begitu mudah tersebar di kalangan mereka terutama apabila dakwah Islam berjaya memasuki istana raja-raja yang kemudiannya bertukar menjadi sultan.

\section{RASIONALISASI}

Sejak daripada awal kedatangannya lagi, mazhab Syafi'i di nusantara berhadapan dengan berbagai adat tempatan yang begitu

29 Lihat: Wan Muhammad 'Ali bin Abd al-Rahman al-Kelantani (t.t.), Zahrat al-Murīd. Kota Bharu: al-Ahmadiyah Press, hh. 8-9;'Uthmān Jalāl al-Dīn (1351H), Mațâli' al-Anwār Wa Majāmi' al-Aẓhār. Patani; Haji Yusuf bin Syihabuddin (1957), Irsyād al-'Ummah Ilā al-Madhāhib al-Arba'ah. Pulau Pinang: Majlis Agama Islam, Adat Istiadat Melayu Selangor. 
mendalam sekali dalam tradisi hidup masyarakat. Sebagaimana maklum, masyarakat nusantara mempunyai sistem perundangan dan adat istiadatnya sendiri sebelum kedatangan Islam. Maka dalam menghadapi keadaan atau melayani suasana seperti ini hukum-hukum dalam mazhab Syafi' ${ }^{\prime}$ i itu kadangkala diubahsuaikan ataupun diabaikan langsung.

Ini bererti meskipun secara teorinya mazhab Syafi'i telah diterima sepenuhnya di nusantara, namun secara praktiknya ia tidaklah diamalkan sepenuhnya, baik sebagai amalan masyarakat mahupun sebagai undang-undang dan peraturan yang dilaksanakan oleh kerajaan. Mengikut teori hukum Islam, hal seperti ini dikaitkan dengan prinsip beransur-ansur (tadarrüj) yang pernah diamalkan pada zaman awal Islam.

Sebagai amalan masyarakat, tidak banyak kajian dibuat. Cuma bolehlah diagak bahawa banyak amalan sama ada yang disifatkan sebagai amalan hidup biasa mahupun yang disifatkan sebagai amalan agama dalam masyarakat Nusantara yang tersasar dari landasan mazhab Syafi'i, malah daripada landasan syariat Islam sendiri. Antara contohnya ialah amalan yang masih kuat dipengaruhi oleh adat lama orang Melayu, baik yang bersendikan agama Buddha atau Hindu, atau yang berasaskan kepada tahayul zaman animisme.

Sebagai undang-undang dan peraturan, contoh paling awal boleh ditunjukkan ialah pelaksanaan peraturan yang tertulis pada Batu Bersurat di Terengganu yang bertarikh pada 17 Rejab $702 \mathrm{H}$, iaitu bersamaan pada 22 Februari 1303M. Sepertimana yang telah disebut di atas, batu bersurat tersebut mengandungi beberapa catatan mengenai hukum Islam yang boleh dilihat sebagai undang-undang yang perlu dilaksanakan. Antara catatan berkenaan ialah tentang tanggungjawab pemerintah melaksanakan dan menguatkuasakan ajaran Islam, pemberian dan penerimaan hutang, hukum rejam atau sebat ke atas penzina, hukum menuduh zina dan tentang kesaksamaan antara semua orang sama ada orang atasan atau orang bawahan. ${ }^{30}$ Walau bagaimanapun sukar untuk dibuktikan bahawa catatan tersebut telah diamalkan sebagai undang-undang yang terlaksana.

30 Lihat: H.S. Peterson (1924), “ The Early Malay Inscription From Terengganu”, dalam JMBRAS, vol.1, part iii (Dec. 1924): 253. 
Satu contoh yang lebih terkemudian ialah peruntukanperuntukan dalam Undang-Undang Melaka. Peruntukanperuntukan tersebut dipercayai merupakan penulisan terhadap hukum-hukum yang sudah lama dilaksanakan dalam bentuk undang-undang tidak bertulis. ${ }^{31}$ Pengumpulan undang-undang tersebut telah dibuat pada zaman pemerintahan Sultan Muzafar Syah (1446-1456). Walau bagaimanapun telah berlaku tokok tambah pada undang-undang tersebut pada zaman pemerintahan yang terkemudian $^{32}$ sehingga menjadi sebagaimana yang terdapat pada hari ini, yang dipercayai disalin pada zaman ketika Sultan Mahmud bersemayam di Bentan (1526-1528) ${ }^{33}$ Walaupun pada dasarnya undang-undang berasaskan Syariat Islam mengikut mazhab Syafi ${ }^{\circ} i$ namun tidak dinafikan terdapat masih banyak pengaruh adat Melayu dalam undang-undang tersebut terutama dalam versiversinya yang awal. ${ }^{34}$

Hal yang sama juga berlaku dalam Undang-Undang Johor yang sememangnya berasal daripada Undang-Undang Melaka dengan sedikit perubahan, ${ }^{35}$ Undang-Undang Pahang yang ditulis pada zaman pemerintahan Sultan Abdul Ghafur Muhyiddin Syah $(1592-1614)^{36}$ di bawah pengaruh Undang-Undang Melaka. Bagaimanapun, berbanding dengan Undang-Undang Melaka, unsur hukum Islam dalam undang-undang ini mempunyai nisbah

31 Lihat: W.G. Shellabear (ed.)(1896), Sejarah Melayu. Singapura: The Malayan Publishing House, h. 96.

32 R.O. Winstedt (1961), The Malay: A Culture History. London: Roulledge \& Kegan, h. 99.

33 Lihat: Abu Hassan Mohd. Sham (1973) "Adakah Hukum Kanun Melaka Mempengaruhi Undang-Undang Melayu Lama Yang Lain”, Dewan Bahasa, April 1973, h. 151.

34 Ahmad Ibrahim \& Ahilemah Joned (1985), Sistem Undang-Undang di Malaysia. Kuala Lumpur: Dewan Bahasa dan Pustaka, hh. 46-47; Ahmad Ibrahim, Towards A History of Law in Malaysia and Singapore. Kuala Lumpur: Dewan Bahasa dan Pustaka, h. 10.

35 Lihat:R.O.Winstedt (1958), "Digest of Laws", dalam JMBRAS, vol. xxxi, part 3 ; M.B. Hooker (1970), Reading In Malay Adat Law. Singapore: University Malaya Press, h. 56.

36 Lihat: J.E. Kempe \& R.O. Winstedt (1984), “A Malay Legal Digest”, dalam $J M B R A S$, vol. 21, part 1. 
yang lebih banyak. ${ }^{37}$ Secara logiknya sebab paling utama kepada hakikat ini ialah perbezaan zaman dan keadaan yang melingkungi kedua-dua undang-undang berkenaan. Sebagaimana diketahui umum, pada waktu Undang-undang Pahang ini ditulis, pengaruh Islam di Tanah Melayu sudah begitu mendalam sekali berbanding dengan sewaktu undang-undang Melaka ditulis.

Begitulah juga yang terjadi kepada undang-undang yang dilaksanakan di negeri-negeri lain yang ditulis terkemudian daripada itu. Semuanya ini memberi erti bahawa walaupun Syariat Islam mengikut mazhab Syafi'i telah diterima secara meluas di Tanah Melayu pada waktu itu dan undang-undang Islam telah menjadi undang-undang negara namun pelaksanaannya sebagai undang-undang masih tidak sepenuhnya kerana terpaksa bertolak ansur dengan kedudukan adat Melayu.

Keadaan seperti ini berlanjutan sampailah kepada saat kerajaan Melaka ditawan oleh Portugis yang dengan sendirinya bererti Malaysia pada waktu itu mula terletak di bawah kuasa penjajahan. Malah di bawah penjajahan Inggeris pemakaian mazhab Syafi ' $i$, iaitu Syariat Islam itu sendiri dalam undang-undang bukan sahaja diganggu oleh adat Melayu tetapi juga oleh perundangan Inggeris.

Sebagaimana maklum Inggeris mula datang menjajah rantau ini pada tahun 1786 dengan melakukan campur tangan di Pulau Pinang. Mereka kemudian menduduki Singapura pada tahun 1819, menerima penyerahan Melaka daripada Belanda pada tahun 1824, masuk ke Perak dan Selangor pada tahun 1874, Negeri Sembilan antara tahun 1874-1886, Pahang pada 1888, Kelantan pada 1910, Johor pada 1914, Terengganu pada 1919, Kedah pada 1923 dan Perlis pada 1930.

Dengan terisytiharnya Piagam Keadilan pertama pada tahun 1807 di Pulau Pinang Syariat Islam, yang bererti mazhab Syafi' $i$ mula disingkirkan dari kedudukannya sebagai asas kepada undangundang negara sepertimana yang berlaku di bawah kerajaan Melaka, Johor, Pahang dan sebagainya sebelum itu. Kemudian dengan berkuatkuasanya Ordinan Perkahwinan Islam di negerinegeri Selat pada tahun 1880, bukan sahaja kedudukan Syariah Islam sebagai undang-undang negara diganggu, malah juga sebagai

37 Ahmad Ibrahim \& Ahilemah Joned (1985), op.cit., h. 47. 
undang-undang agama. Kerana selepas itu satu demi satu negerinegeri di Malaysia telah menerima ordinan-ordinan pentadbiran agama Islam bagi negeri masing-masing berasaskan kepada stail undang-undang Inggeris.

Selain adat Melayu dan kuasa penjajahan, mazhab Syafi‘ $` i$ yang bererti Syariat Islam juga berhadapan dengan arus pemodenan hidup yang bermula sejak kemasukan penjajah sampailah kepada selepas kemerdekaan dan seterusnya sampai ke hari ini. Sepertimana yang disebut di atas tadi, bagi penduduk Nusantara, Syariah Islam sepertimana yang terkandung dalam mazhab Syafi' $i$ itu merupakan suatu nilai yang sangat tinggi berbanding dengan apa yang sedia ada pada mereka baik yang diwarisi dari zaman animisme mahupun dari agama Buddha atau pun Hindu yang mereka anuti sebelum itu.

Bagaimanapun, berbanding dengan nilai hidup barat yang dibawa oleh kaum penjajah kepada mereka itu dalam beberapa keadaan pandangan Syariat Islam sepertimana yang terdapat dalam mazhab Syafi'i itu boleh dipertikaikan. Pada titik inilah pertembungan mula berlaku di antara Syariat Islam sepertimana yang terdapat dalam mazhab Syafi' $i$ itu dengan pandanganpandangan yang berasaskan kepada realiti hidup baru di bawah semangat modernisasi atau pemodenan. Dari perspektif pemikiran Islam pertembungan ini disebut sebagai pertembungan di antara tradisionalisme dan modernisme.

Sampai sekarang ini cabaran modernisme inilah yang paling kritikal sekali bagi mazhab Syafi'i di Malaysia berbanding dengan cabaran adat Melayu yang semakin lemah pengaruhnya dalam masyarakat juga kerana bertembung dengan modernisme.

\section{MODERNISME}

Modernisme sebenarnya berkait rapat dengan penjajahan Barat. Di Malaysia ia boleh dikatakan bermula pada abad ke 18 apabila Inggeris mula menjajah negara ini. Bersamaan dengan proses modernisasi yang dilancarkan oleh kolonialisme Barat itu aliran modernisme telah muncul dalam pemikiran sebahagian daripada umat Islam. 
Pengaruh modernisme dalam pengajian hukum Islam bermula dengan unsur rasionalisme, iaitu kecenderungan menggunakan akal dalam menganalisis hukum. Antara contohnya ialah kecenderungan menggunakan hikmah dan rasional saintifik serta tidak terikat dengan prinsip ta'abbudi iaitu dogmatik. Sebenarnya konsep rasionalisme atau disebut juga sebagai liberalisme ini berkait rapat dengan konsep relativisme, iaitu perubahan hukum. ${ }^{38}$ Berasaskan kepada hakikat ini, bagi aliran modernisme, ijtihad atau rasionalisme diperlukan kerana segala sesuatu, termasuk hukum dan undang-undang bersifat relatif atau nisbi.

Di Malaysia, antara tokoh awal yang diketahui beraliran relativisme dalam masalah hukum ialah ialah Za'ba. Beliau pernah mengecam tindakan kerajaan Afghanistan yang merejam Mulwi Nikmatullah Khan dan rakan-rakannya sampai mati pada bulan Ogos 1925. Bagi beliau semua bangsa yang berperadaban serta berfikiran bebas pada masa sekarang tidak mungkin menerima hukuman yang kejam seperti ini. Agama Islam, kata beliau selanjutnya sebenarnya tidak mempunyai hukuman yang kejam seperti itu. ${ }^{39}$

Syed Hussein al-Atas mempunyai pandangan yang lebih jelas daripada itu. Ketika memperkatakan tentang konsep perubahan hukum dalam Islam beliau telah membezakan antara konsep absalutisme dan relativisme dalam Islam. Menurutnya Islam mempunyai nilai-nilai absalut yang kekal yang tidak terpengaruh oleh ruang dan waktu. Sebagai contoh, kata beliau perbuatan mencuri adalah satu kesalahan yang absalut, tetapi hukumannya bersifat relatif mengikut kondisi ruang dan waktu kejadiannya. Begitu juga hukuman mati yang dikenakan ke atas kesalahan tertentu di zaman lampau kini dianggap kejam dan tidak sesuai lagi. Maksudnya, pada pandangan beliau yang kekal hanya nilai sementara cara atau peraturannya boleh berubah-ubah. ${ }^{40}$

38 Lihat: Muhammad Muslehuddin (1982), Islamic Law and Social Change. Lahore: Islamic Publication, h. 1.

39 Za'ba (1926), "Teguran dan Jawapannya", dalam Al-Ikhwan, Nov. 1926, h. 50.

40 Syed Hussein Alatas (1979), Kita Dengan Islam. Singapura: Pustaka Nasional, h. 16. 
Pandangan yang sama juga dikemukakan oleh Dr. Chandra Muzaffar. Sama seperti Syed Hussein beliau menganggap bahawa yang absalute atau kekal hanyalah nilai al-Quran, sedangkan peraturan yang terdapat di dalamnya tertakluk kepada perubahan. Cuma istilah yang digunakannya sahaja yang berbeza di mana beliau menggunakan istilah progresif dan konservatif, bukan absalut dan relatif. Bagi beliau, aliran progresif berpegang kepada fahaman al-Quran yang dinamis dan berubah-ubah, sedangkan aliran konservatif berpegang kepada fahaman al-Quran yang statik dan kekal. Dalam kesalahan mencuri misalnya kata beliau, perbuatannya memang bertentangan dengan nilai al-Quran. Tetapi bagi golongan progresif tidak semestinya tangan pencuri itu dipotong seperti tuntutan al-Quran. Jika digunakan cara-cara lain sebagai hukuman ia tetap bermakna bahawa nilai-nilai al-Quran masih kekal dipertahankan. Cuma peraturannya sahaja berubah. ${ }^{41}$

Satu contoh lain kepada pemikiran modernisme ialah pandangan Kasim Ahmad. Cuma asas yang beliau gunakan ialah falsafah evolusi. Menurutnya, sesuatu hukuman hendaklah disesuaikan dengan perkembangan masyarakat dan zaman. Malah pada pendapat beliau tidak ada nas al-Quran mengenai perundangan yang bersifat tetap, universal dan muktamad. Dalam hal ini beliau mencuba memisahkan di antara prinsip dan bentuk hukuman. Kata beliau, memang al-Quran menyebut bentuk-bentuk hukuman seperti potong tangan dalam kes mencuri dan rejam dalam kes berzina. Tetapi di samping itu Islam juga mengajar prinsip-prinsip hukuman, iaitu setiap kesalahan mesti dihukum dengan hukuman yang wajar, atau ada kalanya dengan ihsan atau kemaafam. Maksudnya, yang kekal dan abadi hanyalah prinsip hukum, sedangkan bentuk hukuman itu sendiri dapat diubah-ubah bagi disesuaikan dengan keadaan. ${ }^{42}$

Demikianlah beberapa contoh pemikiran yang dikategorikan sebagai modernisme, iaitu suatu aliran yang sangat terpengaruh dengan pemikiran barat. Sama ada pemikiran seperti ini tepat dan wajar atau sebaliknya bukanlah menjadi persoalan dalam

41 Chandra Muzaffar (1979), “Al-Quran: Nilai dan Peraturan”, dalam Utusan Malaysia, 20-21 Disember 1979.

42 Kasim Ahmad (1984), Teori Sosial Moden Islam. Kuala Lumpur: Fajar Bakti, hh. 120-125. 
tulisan ini. Kerana apa yang penting bagi penulisan ini ialah untuk menunjukkan betapa fiqh mazhab Syafi' 'i di Malaysia sekarang menghadapi cabaran besar daripada pemikiran-pemikiran seperti ini. Tentunya bagi aliran pemikiran seperti ini, pandangan mazhab Syafi'i dalam hal-hal yang dimaksudkan tadi begitu mundur sekali dan tidak sesuai dengan perkembangan zaman.

Malah, pemikiran corak ini bukan sahaja dianuti oleh mereka yang berpendidikan sekular seperti penama-penama yang dijadikan contoh di atas. Dalam kalangan mereka yang berlatarbelakangkan pendidikan agama juga pun ada yang mengambil pendirian seperti itu. Selain peranan awal yang dimainkan oleh Syed Syeikh al-Hadi, tokoh lain yang sangat dipengaruhi semangat liberalisme ekstrem ini ialah Haji Nik Muhammad Salleh bin Haji Wan Musa (1920-1971) dari Kelantan.

Dalam kitabnya al-Nafhat al-Muhammadiyah beliau dengan jelas menunjukkan sikap anti terhadap adat dan budaya Arab. Malah beliau menganjurkan pakaian ala barat kerana lebih praktikal terutama bagi memudahkan pergaulan dengan semua bangsa di dunia. Selanjutnya beliau menganjurkan kaum wanita supaya bergaul mengikut cara barat bagi meningkatkan darjat mereka ke arah mencapai kemajuan sepertimana yang dilakukan oleh masyarakat Islam di Turki, Mesir dan bangsa-bangsa lain lagi yang lebih dulu menganut agama Islam daripada umat Islam di Malaysia ini. Bagi beliau al-Quran tidak menentukan corak pakaian tertentu. Antara pendapat beliau yang lain ialah bahawa aurat lelaki dan perempuan di dalam atau di luar sembahyang adalah sama, iaitu kemaluan sahaja, atau biasa disebut sebagai aurat mughallaz̧ah.

Pendapat beliau ini bagaimanapun menimbulkan kontroversi di kalangan masyarakat Islam di negeri itu dan akibatnya kitab tersebut telah diharamkan serta merta oleh Majlis Agama dan Adat Istiadat Melayu Kelantan, iaitu pada tahun 1949. Pada tahun 1951 Majlis Agama tidak lagi memberi tauliah yang membolehkannya mengajar agama di majlis pengajaran yang terbuka. Begitupun pendapatnya tersebar juga melalui usaha para pengikutnya yang dikenali sebagai Jama'ah Pengajian Tariq Syah Dahlawi, Kota Bharu. ${ }^{43}$

43 Lihat: Siti Rekiah Yusuf (1979), "Haji Nik Muhammad Salleh bin Haji Wan Musa (1920-1971) Tokoh Ulama Islah Kelantan”, Latihan Ilmiah, Jurusan Syariah , Universiti Kebangsaan Malaysia. 


\section{REFORMISME}

Usaha merealisasikan Syariat Islam dalam berbagai lapangan hidup di Malaysia sekarang juga merupakan cabaran yang sangat berat terhadap kedudukan mazhab Syafi'i. Bermula dengan masalah ibadat sampailah kepada persoalan antarabangsa, mazhab Syafi' sepertimana yang terdapat dalam kitab-kitab klasik yang menjadi pegangan kuat kalangan tradisionalis di negara ini kelihatannya tidak cukup berwibawa untuk menjawab banyak persoalan yang dihadapi.

Bermula dengan bab țahārah misalnya yang melibatkan masalah batal wuduk kerana bersentuh antara lelaki dan perempuan, masalah hadath yang berbangkit daripada darah perempuan, bab zakat yang melibatkan masalah zakat gaji, zakat getah, kelapa sawit, rumah sewa dan sebagainya. Juga mengenai asnaf penerima zakat, bab muamalat yang berkait dengan perbankan Islam, bab kekeluargaan yang berkait dengan hak wanita dan banyak lagi.

Contoh yang sedikit daripada persoalan yang sangat banyak ini sudah cukup untuk memahami sebab mengapa arus tajdid atau reformisme dalam masyarakat Islam di Malaysia sekarang ini semakin berkembang. Begitupun tidak dinafikan ia sudah mula tumbuh dan berkembang sejak lama sebelum ini dan telah memainkan perananya yang tersendiri baik sebagai aliran yang mencabar kewajaran mazhab Syafi'i atau yang membantu masyarakat mendapat jalan keluar daripada kemelut hukum yang ada.

Reformisme lebih bersifat sebagai usaha pemurnian hukum Islam dengan cara kembali kepada al-Quran dan al-Sunnah dan mentafsirkannya dalam konteks realiti hidup kita sekarang. Istilah yang juga biasa digunakan ialah tajdid dan islah.

Di Malaysia ia lahir hampir serentak dengan aliran modernisme dan juga menyeluruh dalam aktiviti masyarakat setempat. Sebagai suatu gerakan ia bermula di Negeri-Negeri Selat kerana suasananya lebih bebas dan terbuka, berbanding dengan negerinegeri Melayu yang dikawal rapi oleh Sultan dan Majlis-Majlis Agama Islam yang dikuasai oleh golongan tradisionalis. Kerana itulah Singapura merekodkan kemunculan tokoh reformis yang paling awal dilahirkan iaitu Syeikh Muhammad Tahir Jalaluddin 
(1869-1956). Bagi tujuan tersebut beliau bersama rakan-rakan lain menerbitkan majalah al-Imam $^{44}$. Rakan-rakan beliau yang dimaksudkan ialah Syeikh Muhammad Salim al-Kalali, Syed Syeikh alHadi, Syed Muhammad Aqil dan Haji Abas Mohd Taha. Selain melalui majalah pemkiran seperti itu disebarkan juga melalui sekolah-sekolah agama yang didirikan di merata tempat berasaskan pendekatan baru.

Di Melaka ${ }^{45}$, pada tahun 1917 Syed Syeikh al-Hadi memulakan penubuhan sekolah agama yang serupa dengan yang terdapat di Singapura dengan sokongan berbagai kalangan yang menyambung misinya apabila beliau berpindah ke Pulau Pinang untuk mendirikan Madrasah al-Masyhur al-Islamiyah pada tahun 1919. ${ }^{46}$ Sekolah ini berasaskan sistem pendidikan moden yang sama dengan yang terdapat di sekolah Inggeris dan Melayu pada waktu itu. Pada tahun 1926 beliau menulis novel Hikayat Faridah Hanum yang mengandungi idea tentang pembaharuan dan kemudian menerbitkan majalah al-Ikhwan pada tahun 1926 dan Saudara pada tahun 1928 bagi tujuan yang sama.

Di Perak, gerakan seperti ini mula bertapak apabila Syeikh Abdullah Maghribi dijemput untuk memimpin Madrasah Idrisiyah yang ditubuhkan pada tahun $1922 .{ }^{47}$ Begitupun yang paling berkesan ialah ustaz Abu Bakar al-Baqir yang telah mendirikan Madrasah al-Ihya' al-Syarif di Gunung Semangol pada 15 April $1934 .{ }^{48}$

44 Abu Bakar Hamzah (1990), al-Imam: Its Role in Malay Society 1906-1908. Kuala Lumpur: Media Cendikiawan, h. 120.

45 Abdul Aziz Mat Ton (1974), "Kaum Muda di Melaka” dalam Jurnal Sejarah, jld. XII, hh. 36-38.

46 Muhammad bin Daud (1980), "Madrasah al-Masyhur al-Islamiyah Pulau Pinang:1916-1969”, Latihan Ilmiah, Universiti Kebangsaan Malaysia.

47 Mohd. Sarim Haji Mustajab (1975), "Sayid Syeikh Abdullah Magharibi: Pendidikan dan Kaum Muda", dalam Jebat, no. 5, hh.1-6.

48 Nabir Haji Abdullah (1976), "Ma'had al-Ihya' al-Syarif Gunung Semanggol 1934-1959”, Latihan Ilmiah jurusan Sejarah, Universiti Kebangsaan Malaysia, hh. 34-35. 
Di Selangor, aliran reformisme ini mula bertapak pada tahun 1922 apabila Madrasah al-Ubudiyah ditubuhkan di Jenderam oleh Haji Jalaluddin bin Ismail dari Minangkabau. Sebelum itu, iaitu pada tahun 1920 telah berlaku konflik di antara golongan ini dengan golongan tradisionalis mazhab Syafi' $i$ tentang keperluan berdiri sewaktu berselawat pada perayaan maulidulrasul. ${ }^{49}$

Pada tahun 1942, di Negeri Sembilan telah ditubuhkan kumpulan "Ittiba' al-Sunnah" yang kemudian mendirikan sebuah madrasah di Kuala Pilah. Di antara madrasah ini yang juga dikenali sebagai golongan kaum muda dan Majlis Agama Islam dan Adat Istiadat Melayu Negeri Sembilan yang didominasi oleh ulama mazhab Syafi'i, atau digelar juga sebagai Kaum Tua sentiasa terjadi konflik, terutama dalam hal-hal mengenai bid'ah dan sebagainya. ${ }^{50}$

Gerakan seperti ini kemudiannya telah mencapai kemuncaknya di Perlis apabila Undang-Undang Tubuh Negeri itu pada tahun 1959 mengakui kedudukan "Ahlu Sunnah Wal Jamaah", dengan dikuti pada tahun 1963 dengan ketentuan bahawa setiap fatwa hendaklah berdasarkan al-Quran dan al-Sunnah dan bukan ajaran mazhab.

Gerakan al-Sunnah ini bermula di negeri tersebut dengan kedatangan Lebai Kecik dari Indonesia yang menyeru kembali kepada al-Quran dan al-Sunnah. Walau bagaimanapun peranan utama menyebarkan fahaman tersebut di Perlis ialah Haji Ahmad bin Haji Muhammad ${ }^{51}$, Wan Ahmad bin Wan Daud ${ }^{52}$ dan Syeikh Ahmad bin Mohd. Hashim ${ }^{53}$. Mereka merupakan tokoh-tokoh

49 Mohd Nor bin Mohd Amin (1978), "Jenderam-Korban Darurat 19481958”, Latihan Imiah, Jurusan Sejarah, Universiti Malaya.

50 Wan Nawang Sulung (1983), "Kumpulan Ittiba' us-Sunnah di Kuala Pilah, Negeri Sembilan", Latihan Ilmiah, Fakulti Pengajian Islam, Universiti Kebangsaan Malaysia, hh. 56-58.

51 Lebih terkenal sebagai Haji Ahmad Hakim (1885-1964). Pernah menjadi Hakim Besar Perlis dan kemudiannya Yang Di Pertua Majlis Agama Islam Perlis yang pertama.

52 Beliau ialah Dato' Wan Ahmad, Jurubicara pertama Dewan Undangan Negeri Perlis serta Senator mewakili Negeri Perlis.

53 Beliau ialah Tan Sri Dato' Syeikh Ahmad, Menteri Besar Perlis (1959-1971). 
pelaksana kepada idea tersebut, sementara tokoh pemikirnya ialah Syeikh Abu Bakar al-Asyaari. ${ }^{54}$

Di Kelantan, sejarah gerakan seperti ini bermula dengan kehadiran seorang ulama dari India yang bernama Syed Hasan bin Nur Hasan, atau lebih dikenali sebagai "Tok Khurasan"(18751944). ${ }^{55}$ Antara pengikut beliau yang terkemuka ialah Haji Nik Abdullah bin Haji Wan Musa (1900-1935), Haji Abdullah Nuh (1905-1047) yang telah mendirikan sebuah madrasah yang diberi nama Madrasah al-Balagh al-Mubin pada tahun 1939.

Sebelum zaman mereka ini, pendirian yang serupa telah pun diperjuangkan oleh seorang ulama tradisional Kelantan bernama Haji Wan Musa bin Abd Samad (1874-1939). Seorang lagi yang berpendirian serupa ialah Haji Yaakob bin Haji Ahmad (1895-1957). ${ }^{56}$ Seorang lagi ialah Haji Muhammad bin Haji Mohd Said Khatib (1888-1939), yang juga dikenal sebagai Dato' Laksmana ${ }^{57}$.

Begitulah secara ringkas tentang aliran refomisme yang berlaku dalam sejarah Malaysia. Ia boleh dikatakan menyeluruh dan di bawah berbagai nama. Namun lebih jelas mereka ini boleh disifatkan sebagai pendukung al-Sunnah dengan erti meninggalkan warisan fiqh yang dikatakan sebagai lapuk dan hanya sesuai dipegang oleh golongan tradisionalis sahaja. Sebab itu mereka lebih suka dikenali dengan nama "al-Sunnah", seperti "Ansar alSunnah" di Melaka "Ittiba' al-Sunnah" di Negeri Sembilan, dan "Ahl al-Sunnah Wal-Jamaah" di Perlis.

Sesuai dengan zaman mereka sendiri, fokus yang diberikan dalam usaha mereka untuk kembali kepada al-Quran dan al-Sunnah ialah memerangi bid'ah. Bagi mereka bid'ah telah mengotori

54 Lulusan al-Azhar, dan pernah menjadi Imam Besar Masjid Alwi, Kangar.

55 Lihat: Nik Abdul Aziz Nik Hasan (1957) "Tok Khurasan: Seorang Tokoh Ulama Kelantan” dalam Malaysia in History, vol. 18, no. 1, hh. 29-34.

56 Lihat: Ismail Awang (1976) "Haji Yaakob Haji Ahmad Gajah Mati" dalam Pengasuh, no. 414, April 1976.

57 Lihat: Ismail Awang (1976), "Dato' Laksmana(1888-1939)", dalam Pengasuh, no. 412, Januari/Febuari 1976. 
kemurnian agama ${ }^{58}$. Oleh kerana itu para ulama hendaklah menjauhkan diri daripada perbuatan bid'ah yang menyesatkan dan tidak diperintah oleh Allah dan RasulNya. ${ }^{59}$

Selain daripada itu mereka menolak taqlid kepada mana-mana mazhab. Dengan menolak taqlid bererti mereka menggalakkan ijtihad. Oleh kerana itu mereka melihat ulama tradisional yang bertaqlid kepada mana-mana mazhab itu sebagai berusaha ke arah kebodohan. ${ }^{60}$ Lebih jauh daripada itu mereka mengatakan bahawa menganut sesuatu mazhab itu adalah haram, kerana itu kita wajib keluar darinya. ${ }^{61}$

Walau bagaimanapun skop perbincangan yang dilakukan oleh golongan reformisme ini sangat sempit, iaitu tertumpu kepada masalah ibadat sahaja, yang dikatakan oleh mereka sebagai telah dijangkiti penyakit bid'ah. Kerana itu perbincangan lebih tertumpu kepada masalah-masalah seperti "najis mughallazah"62, masalah membaca al-Fātị̣ah dalam sembahyang sama ada patut nyaring atau sebaliknya, membaca "wa biḥamdih" ketika sujud, menyebut perkataan "saiyidinā" ketika berselawat untuk Rasul, dan sebagainya.

Antara contoh lain ialah masalah wirid lepas sembahyang berjema'ah, sujud sahwi, doa qunut, bilangan sah sembahyang Jumaat, azan Jumaat, bilangan solat tarawih, talqin, kenduri arwah dan sebagainya.

Makalah ini tidak bertujuan untuk membincangkan persoalan berkenaan atau pendirian mana-mana pihak. Apa yang penting untuk diperkatakan di sini ialah pandangan-pandangan "Kaum

58 Syed Syeikh al-Hadi (1926), "Peraturan Mengajar Dalam Masjid alHaram al-Musyarrafah", dalam al-Ikhwan, Peng. 4, jilid 1, 16 Sept, h. 81 .

59 Rahim Kajai (1931), "Pertolongan Utama" dalam (Editorial) Saudara, 11 April, h. 5.

60 Rahim Kajai (1930), "Pencanai Otak", dalam (Editorial) Saudara, 11 Oktober, h. 5.

61 Hashim Abd.Ghani (1984), Gayong Bersambut Kedua: Al-Sunnah Membela Diri. Kuala Pilah: KTF.

62 Lihat: Nik Aziz Nik Hasan (1979/1980), “ Perbahasan Tentang Jilatan Anjing: Suatu Perhatian, dalam Jebat, no.9, hh.173-180. 
Muda" atau "Para Pendukung Sunnah", sepertimana yang mereka suka dikenali ini merupakan cabaran secara langsung terhadap mazhab Syafi‘i yang merupakan satu-satunya mazhab yang diamalkan di Malaysia.

Perbezaan pendapat di antara para pendukung aliran Sunnah ini dan pendukung setia mazhab Syafi'i di Malaysia yang biasa juga dikenali sebagai "Kaum Tua" atau golongan tradisionalis telah melahirkan suasana tegang dan kadangnya perkelahian di peringkat akar umbi. Bagaimanapun dari segi pembangunan intelektual tidak banyak faedah yang didapati, kerana metod perbahasan biasanya tidak berasaskan kepada prinsip ilmiah yang cukup.

Sejauh mengenai para pendukung mazhab Syafi' $i$ di Malaysia sendiri secara khusus, cabaran golongan reformis ini sepatutnya menyedarkan mereka bahawa sesuatu perlu dilakukan demi kesinambungan tradisi bermazhab dan bagi mengekalkan kedudukan atau pengaruh mazhab berkenaan di negara ini.

\section{PERKEMBANGAN SEMASA}

Paling kritikal terhadap kedudukan mazhab Syafi'i di Malaysia ialah apa yang boleh disebut sebagai perkembangan semasa yang tidak membantu baginya untuk terus dominan tanpa digugat. Bagi memudahkan perbincangan elok sekali kalau perkembangan semasa yang tidak membantu ini dipecahkan kepada dua, iaitu perkembangan dalaman dan perkembangan luaran.

Yang dimaksudkan dengan perkembangan dalaman ialah yang berkait dengan kedudukan mazhab itu sendiri dalam kalangan masyarakat Islam di Malaysia. Sebagaimana maklum, pengembangan mazhab Syafi 'i di Malaysia, sama juga di Nusantara secara umumnya telah mencapai kejayaan dalam nisbah yang begitu tinggi melalui sekolah pondok yang dibangunkan di seluruh negara. Sekolah- sekolah inilah yang berperanan melahirkan para pendukung mazhab Syafi'i yang setia di setiap peringkat.

Namun selepas perang dunia kedua sekolah-sekolah pondok ini mula pupus dengan digantikan dengan sekolah-sekolah agama/ Arab dalam bentuk yang dimulakan oleh golongan reformis 
semasa awal kebangkitan mereka. Sebagai contoh, di negeri Kelantan sekolah seperti ini mula ditubuhkan pada tahun 1917, iaitu dengan tertubuhnya Sekolah Ma'had Muhammadi Melayu Lelaki. Ini dikuti dengan Madrasah Muhammadiah al-Arabiyah yang dirasmikan pada tahun 1937. Pada tahun 1952 terdapat 10 buah sekolah Arab yang ditadbir sepenuhnya oleh Majlis Ugama Islam dan Adat Istiadat Melayu Kelantan. Pada tahun 1959 jumlah sekolah agama rakyat yang berdaftar di bawah Majlis ialah sebanyak 47 buah, dan pada tahun 1966 menjadi 134 buah. ${ }^{63}$

Tidak seperti di sekolah-sekolah pondok, di sekolah-sekolah agama seperti ini terdapat keterbukaan yang nyata tentang mazhab dari segi pengajiannya walaupun dari segi anutannya tetap tidak berubah. Apatah lagi apabila pusat-pusat pengajian Tinggi Islam di buka iaitu Kolej Islam Malaya pada tahun 1955, Jabatan Pengajian Islam Universiti Malaya pada tahun 1959, Yayasan Pengajian Tinggi Islam Kelantan pada tahun 1965, Fakulti Pengajian Islam Universiti Kebangsaan pada tahun 1970, Akademi Islam pada tahun 1981 dan seterusnya sepertimana yang ada pada hari ini.

Khusus mengenai pengajian hukum, kecenderungan yang terdapat di sekolah-sekolah agama, terutama sekali di pusat-pusat pengajian tinggi ialah dalam bentuk terbuka dan tidak terikat dengan mazhab. Malah persoalan tentang mazhab seolah-olah dilupakan begitu sahaja terutama kerana buku-buku teks dan buku-buku rujukan tidak lagi mengambil kira hal seperti itu.

Hal seperti ini bukan sahaja berlaku di Malaysia, tetapi juga di seluruh dunia Islam di mana hasil daripada reformasi Muhammad Abduh terhadap corak pendidikan di Universiti al-Azhar telah merubah wajah dan corak pengajian Syariah di seluruh dunia. Maksudnya, bagi institusi-institusi pengajian tinggi Islam ini, soal mazhab tidak lagi berbangkit. Apa yang dipentingkan ialah corak pengajian yang lebih objektif dengan merujuk kembali kepada al-Quran dan al-Sunnah dan mengambil kira pandangan mazhab sebagai tradisi berfikir yang perlu diambil kira secara umum. Di bawah suasana seperti ini fiqh al-Zahiri dihidupkan semula oleh al-Azhar sendiri dengan menerbitkan kitab penting mazhab tersebut al-Muhallā karangan Ibn Hazm al-Ẓahirí, setelah

63 Lihat: Nik Abdul Aziz bin Haji Nik Hasan (1983), Islam di Kelantan. Kuala Lumpur: Persatuan Sejarah Malaysia, hh. 94-98. 
sebelum itu dianggap sebagai warisan yang tidak berharga. Malah usaha-usaha untuk memperdekatkan pandangan antara mazhab Sunni dengan mazhab Syiah pun pernah dilakukan.

Sedangkan pengajian pondok terus malap, bukan sahaja kerana ketiadaan pelajar tetapi juga kehilangan dukungan. Memang ada usaha-usaha untuk menghidupkan semula pengajian corak ini terutama di Kelantan sekarang, tetapi kejayaannya sukar untuk dilihat dan mungkin ramai orang berpendapat ianya sebagai suatu langkah yang tidak sesuai dengan keadaan dan perkembangan semasa.

Yang dimaksudkan dengan perkembangan luaran pula ialah perkembangan corak hidup baru yang terdapat di negara ini, sama seperti di negara-negara lain juga. Di bawah corak hidup baru ini masyarakat memerlukan jawapan yang semasa terhadap berbagai persoalan hukum bermula dari masalah taharah sampailah kepada masalah jihad yang jawapannya tidak ada dalam kitab-kitab warisan mazhab Syafi' $i$ yang ada. Malah dalam beberapa hal yang bukan sedikit jawapan yang terdapat dalam kitab-kitab berkenaan dilihat sebagai tidak begitu tepat atau ada-ada sahaja yang kurang di dalamnya.

Di antara țaharah dan jihad ada ruang hidup yang sangat luas terutama di zaman global ini di mana dunia telah menjadi sempit dan langit telah terbuka dan tidak lagi mampu memayungi manamana negara atau umat. Pertembungan budaya dan tamadun dengan kemenangan sentiasa berada di tangan barat sekarang ini menjadikan umat Islam sentiasa merasa gelisah mencari penyelesain yang semakin sukar diperolehi bukan sahaja dari segi politik, ekonomi dan ketenteraan tetapi juga dari segi kehidupan harian yang sesetengahnya pula menyangkuti persoalan tentang hukum.

Di bidang perbankan Islam sahaja, bukan sahaja pandangan mazhab Syafi'i tidak mampu digunakan sepenuhnya untuk melayani keperluan sistem yang sedang dibangunkan, malah juga boleh dikatakan semua mazhab yang ada. Kerana itulah para ulama besar kontemporari, seperti Dr. Yūsuf al-Qaraḍāwī dan ramai lagi yang tidak tahu untuk disebut nama mereka di sini sentiasa mencadangkan berbagai-bagai corak ijtihad semasa bagi 
mengatasi hal-hal seperti ini. Persoalannya, kata mereka, sama ada kita berubah atau kita ditinggalkan.

Ringkasnya, mazhab Syafi'i di Malaysia, malah mazhab lain juga di mana-mana sahaja yang berkait dengan fiqh atau ilmu hukum berada dalam keadaan yang sangat kritikal. Di Malaysia, mazhab ini paling bernasib baik sekali kerana disokong oleh undang-undang pentadbiran Islam di negeri-negeri dan oleh para birokrat pentadbiran hal ehwal agama Islam, seperti mufti dan pegawai-pegawai agama yang lain. Begitupun pada hakikat sebenarnya sokongan ini tinggal pada namanya sahaja, kerana sudah banyak fatwa dan amalan pentadbiran hal ehwal agama Islam di negara ini sudah mengambil kira berbagai mazhab yang ada , malah juga tanpa berasaskan kepada mana-mana mazhab. Lebih dari itu kadangkala sokongan itu sendiri menjadi bak kata pepatah Melayu sebagai "sokongan membawa rebah".

\section{PERSOALAN MASA DEPAN}

Dalam buku beliau al-Fikr al-Qānūnì al-Islāmì Baina Usūl alSyarī'ah al-Islāmiyah Wa Turāth al-Fiqh, ${ }^{64}$ Dr. Fatḥi 'Uthmān menyebut:

" Fiqh Islam sekarang berada di persimpangan jalan yang kritikal. Arah pertama membawa kepada pembekuan hukum dan terus berpegang dengan apa yang dikatakan oleh para ulama taqlid di zaman kejatuhan. Sementara jalan kedua bertujuan untuk memahami syariah berasaskan pengertiannya yang hakiki dan semangat ketamadunannya yang original yang terbina atas konsep keadilan yang tulen dan kemajuan serta pembangunan. Jalan inilah yang dilalui oleh golongan salaf terdahulu pada zaman kegemilangan dan ijtihad. Kerana itu masa depan syariah Islam bergantung kepada pilihan kita sendiri di antara dua jalan yang tiada jalan ketiganya ini. Ia perlu dibuat segera dan tidak boleh tawar menawar atau berlengah lagi". ${ }^{65}$

\footnotetext{
64 Fathịi 'Uthmān (t.t.), al-Fikr al-Qānūnì al-Islāmì Baina Uṣū al-Sy rīah Wa Turāth al-Fiqh. Kaherah: Maktabah Wahbah.

65 Ibid., h. 24.
} 
Getusan ini sengaja dibuat untuk memberi gambaran tentang pandangan sesetengah mereka yang prihatin tentang masa depan fiqh secara umum tanpa mengira mazhab apa ianya pada hari ini. Sebagai seorang penyelidik yang prihatin terhadap kemajuan Syariah Islamiah Dr. Fathi merasa amat kecewa terhadap gejala taqlid yang sangat meluas di dunia Islam pada waktu itu dan mengajak masyarakat Islam berbuat sesuatu secara drastik supaya gejala yang merugikan ini dapat dihapuskan dan diganti dengan gejala lain yang lebih baik dan menguntungkan, iaitulah gejala ijtihad. Dengan kata lain beliau mengajak umat Islam kembali kepada fiqh Islam yang original.

Nada yang sama terdapat dalam penulisan banyak orang, sejak daripada al-Syeikh 'Abd al-Wahāb Khallāf dan al-Syeikh Muhammad Abū Zahrah sampailah kepada al-Syeikh Muhammad al-Ghazāli dan al-Syeikh Dr. Yūsuf al-Qaraḍāwì. Kata Dr. Yūsuf al-Qaraḍāwì dalam buku beliau al-Ijtiḥād al-mu'āṣir Baina alIndibāt Wa al-Infirāt. ${ }^{66}$

"Soalan paling awal yang timbul dalam diri kita sewaktu memperkatakan tentang ijtihad semasa ialah: Apakah betul kita benar-benar memerlukan kepada ijtihad? Ada kemungkinan sesetengan mereka yang banyak berusaha di bidang keilmuan Islam,kerana sangat kagum dengan warisan keilmuan kita yang sangat kaya itu, dan kerana sangat yakin denga para fuqaha besar kita, akan terus menegaskan bahawa kita sebenarnya tidak perlukan apa-apa ijtihad yang baru. Kerana apa saja persoalan yang timbul pada hari ini ia sebenarnya pernah berbangkit pada zaman para fuqaha tertdahulu. Fara fuqaha itu telah berijtihad berasaskan realiti zaman mereka, dan mereka juga telah membuat andaian apa akan berlaku selepas mereka. Kerana itu kita tidak lagi perlu kepada apa-apa ijtihad selepas daripada para fuqaha kita yang sangat ulung itu. Segala tangkapan sudahpun berada di dalam raga. Hanya apa yang kita perlu buat ialah kembali kepada kitab-kitab mereka dan meneliti setiap baris yang terdapat di dalamnya. Di situ kita akan mendapat

${ }^{6}$ Yūsuf al-Qaraḍāwì (1994), al-Ijtihāad al-mu 'āṣir Bayna al-Indibāt Wa al-Infirāt. Kaherah: Dār al-Tauzi’’ Wa al-Nasyr al-Islāmiyyah. 
jawapan yang jika mahu sama ada dalam bentuk nas atau qiyas atau takhrij”. ${ }^{67}$

Menjawab tanggapan tersebut al-Qaraḍāwi menulis seterusnya:

"Kita tidak bertujuan langsung untuk memperkecilkan nilai warisan kita, tidak juga keagungan fiqh kita dengan segala cabang yang ada dan alirannya yang berbagai-bagai, juga segala ijtihad yang ada samada yang berasaskan realiti semasa atau andaian untuk masa depan. Begitu pun, dengan secara jujur saya ingin berkata, adalah suatu keterlaluan dan penafian terhadap kenyataan untuk mengatakan bahawa kitab-kitab lama itu mengandungi jawapan terhadap semua persoalan yang baru. Kerana setiap zaman ada persoalannya yang tersendiri, realitinya yag tersendiri dan keperluannya yang tersendiri dan lagi sentiasa berubah-ubah. Bumi ini terus berpusing, cakrawala terus bergerak, dunia berjalan terus dan jarum jam tidak pernah berhenti. ${ }^{\prime 68}$

Mengenai kemungkinan semua persoalan sudah pun terjawab dalam kitab-kitab para ulama terdahulu itu, al-Qaraḍāwi menegaskan:

"Sesuai dengan perkembangan hidup yang berlaku banyak perkara yang tidak pernah dikenali olah orang terdahulu, malah mereka mungkin tidak terkhayal mengenainya. Ada kemungkinan mereka akan mengatakan seseuatu yang terjadi pada hari ini sebagai mustahil boleh berlaku kalau disebut kepada mereka pada zaman itu. Maka bagaimanakah kita boleh fikir mereka telah memberi hukum tentangnya sedangkan mereka sendiri tidak pernah kenal perkara seperti itu. ${ }^{\circ 9}$

Kesesuaian kenyataan awal ini dibuat sebelum perbincangan tentang prospek masa depan mazhab Syafi'i di Malaysia dibuat memang ada. Adalah lebih baik dalam persoalan-persoalan seperti ini kita mempersempitkan ruang untuk berbeza pendapat supaya

\footnotetext{
$67 \quad$ Ibid., h. 5.

68 Ibid.

69 Ibid.
} 
tumpuan kepada yang lebih diutamakan boleh dibuat. Maksudnya, untuk mempertahankan kewajaran fiqh mazhab Syafi' $i$ sepertimana seadanya sekarang untuk menjadi mazhab yang dominan terus menerus sampai kepada bila-bila masa ada alasannya yang cukup. Namun adalah baik untuk mazhab Syafi'i sendiri kalau ianya cuba dianalisis berdasarkan keperluan semasa agar kemampuannya dapat dipertingkatkan.

\section{ANTARA HADITH DAN FIKIRAN}

Sepertimana maklum, mazhab Syafi'i mula tumbuh di Iraq, iaitu hasil gabungan ilmu Mekah, Madinah, Baghdad dan Kufah. Keilmuan Mekah dan Madinah mewakili aliran Hadith yang sifatnya lebih dogmatik dan rigid, sementara keilmuan Baghdad dan Kufah mewakili aliran fikiran yang sifatnya lebih sekular dan pragmatik. Dari segi ini ia boleh disifatkan sebagai rumusan semua ilmu yang ada pada waktu itu dan tegak sebagai suatu permula baru buat menyatukan kembali pemikiran yang sudah bersimpang siur selepas zaman Rasulullah dan Khulafă’ al-Rāsyidīn.

Malah pengasasnya sendiri, Imam Syafi' $i$ secara peribadi merupakan adunan antara dua darjat. Dalam dirinya ada darah bangsawan kerana dia berketurunan Quraisy. Namun ayahnya sendiri seorang perantau miskin yang mati di perantauan sebaik sahaja dia dilahirkan. Dia sendiri dibesarkan oleh seorang ibu tunggal yang tidak mempunyai mata pencarian yang boleh menampung keperluan mereka berdua. Orang seperti ini tentu sekali memiliki watak tertentu yang mempengaruhi corak pemikirannya. Biasanya dia menjadi seorang yang sangat berhati-hati dalam menilai sesuatu.

Kota Baghdad di mana mazhab Syafi'i dilahirkan ialah sebuah kota kosmopolitan tempat berlakunya pertembungan antara banyak pihak; antara tamadun Islam yang masih muda dan warisan tamadun Parsi yang sangat kaya dengan pengalaman, antara kaum pendatang Arab yang berkuasa di bidang politik dan kaum asli Parsi yang berkuasa di bidang ilmu dan budaya, antara kebenaran Islam dan kebatilan berbagai-bagai agama dan kepercayaan hidup dan sebagainya. 
Malah tempat kelahiran keduanya pun begitu, iaitu Kaherah. Sebagaimana maklum, atas sebab-sebab tertentu, Imam Syafi'i membuat keputusan meninggalkan kota Baghdad dan berpindah ke Kaherah sebelum mazhabnya belum cukup matang di Kota Abbasiah itu. Kaherah juga sebuah kota kosmopolitan yang terdapat banyak kontradiksi. Bagaimanapun di situ tiada orang Parsi. Yang adanya ialah orang Mesir yang keislaman mereka seumur dan sebaya dengan keislaman orang Baghdad. Di sini Imam Syafi' $i$ merombak kembali struktur fatwanya dalam suatu langkah tajdid yang menyeluruh. Lalu lahir suatu aliran baru yang dikenali sebagai Qaul Jadid sebagai ganti kepada aliran lama di Baghdad yang kemudiannya dikenali sebagai Qaul Qadim.

Bagaimanapun yang tidak dirombak oleh beliau ialah Usul atau metodologi kepada fiqhnya yang terkandung dalam bukunya al-Risālah. Walaupun buku ini ditulis pada mulanya sekadar untuk menjawab persoalan yang ditanya namun jawapan yang lengkap kepada pertanyaan itu menjadikan buku itu sebagai suatu cacatan yang menyeluruh tentang metodologi berkenaan. Malah ia dianggap sebagai penyusunan paling awal terhadap ilmu Usul Fiqh sebagai suatu disiplin ilmu yang tersusun sesudah beratus-ratus tahun diwarisi dengan secara praktikal sahaja.

Maksudnya, dalam berfikir tentang prospek masa depan mazhab Syafi'i di negara ini kita perlu memisahkan diantara Usūl al-Syāfi 'iyah dan Furū' al-Syāfi 'iyah. Kerana walaupun kedua-duanya merupakan Fiqh tetapi ada banyak perkara yang membezakan di antara keduanya. Kerana itulah dalam memberi pengertian terhadap konsep fiqh itu sendiri para ulama Usul dan para ulama Furū' berbeza pendapat. Bagi ulama usul, sekadar memahami fatwa yang sudah ada bukan fiqh namanya, kerana fiqh perlu usaha yang lebih jauh daripada itu, iaitu memahami hukum daripada dalil-dalilnya yang terperinci. Dengan kata lain, dalam kitab fiqh warisan itu tidak ada fiqh. Apa yang ada hanyalah warisan fiqh.

Sewaktu Imam Syafi' $'$ bergiat di bidang fiqh beliau mendapati ada dua keterlaluan yang bertentangan di antara satu sama lain. Kedua-duanya ialah penggunaan hadith tanpa analisis oleh aliran hadith di Hijaz dan penggunaan fikiran tanpa panduan hadith di Iraq. Kritik beliau terhadap dua ektrimisme ini cukup keras sekali, 
sama kerasnya dengan kritik beliau terhadap penggunaan prinsip Istiḥsān oleh mazhab Hanafi. Begitupun akhirnya beliau sampai kepada suatu rumusan yang boleh diterima umum, iaitu menerima penggunaan hadith secara meluas seperti amalan aliran Hijaz dengan syarat hadith-hadith itu dianalisis dan bukan diamalkan begitu sahaja. Begitu juga pemikiran secara meluas sepertimana yang diamalkan oleh aliran Iraq juga diterima dengan syarat kerangka pemikiran itu dibentuk berdasarkan lunas-lunas hadith. Dengan itu beliau dapat melahirkan sesuatu yang baru, yang merupakan rumusan secara adil daripada semua yang ada. Beliau lalu diterima oleh kedua-dua belah pihak. Malah oleh golongan Hadith beliau digelar sebagai Nașir al-Sunnah.

Pertentangan di antara dua pembawaan yang ekstremis inilah juga yang berlaku pada hari ini. Cuma coraknya agak berbeza. Pada hari ini pertentangan berlaku di antara golongan tradisionalis yang berkecenderungan mempertahankan hasil pemikiran atau ijtihad lama dalam mazhab atas alasan ianya telah mencapai tingkat keunggulan yang tinggi dan luar biasa, dan golongan reformis yang melihat hasil pemikiran tersebut telah dikotori oleh debu zaman dan perlu dibersihkan dengan cara kembali kepada sumber yang asal. Kekurangan yang berlaku dalam kedua-duan aliran ini ialah ketiadaan petunjuk yang cukup jelas tentang bagaimana caranya sama ada untuk mempertahankan yang lama atau memperkenalkan yang baru dalam bentuk yang benar-benar praktikal.

Sebagai suatu penyelesaian perlu ada persefahaman di antara kedua belah pihak tentang perlunya kepada ijtihad baru dalam bentuk yang munasabah. Kerana sepertimana kata al-Qaraḍāwí, menafikan ijtihad baru seperti itu bererti menafikan realiti hidup yang sedang berlaku. Begitu pun dalam berijtihad, metodologi mazhab Syafi'i perlu dikekalkan. Kerana tanpa pengekalan mazhab ini kesinambungan dalam bidang perhukuman akan hilang dan tradisi amalan berasaskan syariah Islam tidak menpunyai tapak yang kukuh untuk berpijak.

Oleh kerana itu apa yang perlu dipertahankan daripada mazhab Syafi' $i$ ialah Ușul atau metodologinya, dan bukan warisan ijtihadnya. Dalam falsafah orang Cina, kailnya dan bukan ikannya. Sementara pembaharuan sepertimana yang diperlukan oleh golongan reformis 
atau pun juga kalangan profesional boleh terus berlaku tetapi perlu tunduk kepada prinsip dan metodologi hukum mazhab Syafi ‘i.

Bagi al-Qaraḍawi, ijtihad yang dimaksudkan boleh berlaku dalam dua bentuk. Pertamanya melakukan ulangkaji literatur (literature review) bagi melihat kembali pandangan-pandangan yang ada untuk mempastikan ketepatan sama ada dari segi nas atau aplikasinya dalam masalah berkenaan (الانتقائي). Keduanya pula ialah melakukan ijtihad baru terhadap permasalahan baru bagi mencari jawapan semasa (الإنشائي). Dalam kedua-dua hal ini pendekatan tempatan adalah sangat penting. Kerana sejak daripada zaman Imam Syafi'i lagi hal berkenaan sentiasa diambil kira. Kalau tidak manakan ada mazhab qadìm dan mazhab jadìd dalam fiqh beliau, sedangkan manhaj atau metodenya hanya satu, sepertimana yang terdapat dalam al-Risālah. Malah manakan ada aliran Baghdad dan aliran Khurasan dalam fiqh para pengikutnya. Menariknya kedua-dua aliran ini diterima sepenuhnya oleh masyarakat nusantara sejak daripada awal kedatangan mazhab Syafi'i ke sini lagi, iaitu masing-masing diwakili oleh hasil karangan al-Nawawi dan hasil karangan al-Syirāzi. Atas asas ini tentulah tidak menjadi masalah kalau yang dibangunkan itu ialah Fiqh Malaysia berasaskan kepada manhaj al-Syafi i.

\section{PENUTUP}

Sebagai kesimpulannya, mazhab Syafi'i masih mempunyai masa depan yang cukup terjamin dinegara ini. Pertama, kerana sejarahnya yang begitu cemerlang. Keduanya, kerana ia telah diterima oleh akar umbi masyarakat dan telah merupakan sebahagian daripada budaya mereka. Ketiganya, sifatnya yang sederhana dan sesuai dengan kesederhanaan corak hidup masyarakat rantau ini. Keempatnya, kerana ada sokongan undang-undang. Kelimanya, kerana ada barisan pendukung yang terus menguasai birokrasi.

Namun tanpa pembaharuan ia tidak boleh bertahan lama dengan selesa. Pertamanya kerana yang sedang diamalkan sekarang adalah mewakili rumusan zaman dan budaya hidup yang berbeza daripada apa yang ada di sini sekarang. Keduanya, kerana yang dimaksudkan ialah hasil ijtihad zaman lampau dan bukannya metode ijtihad atau dalam bahasa yang digunakan 
oleh al-Qaraḍāwi, hasil tangkapannya dan buka jaring atau jalanya. Ketiganya, kerana perubahan keadaan yang terlalu pesat. Keempatnya, kerana fiqh berkenaan mula menampilkan dirinya dalam urusan yang jauh lebih komplikated daripada apa yang ada pada masa lampau, misalnya sistem kewangan Islam.

Maka caranya yang paling baik ialah memperbaharui fiqh ini berasaskan metode al-Syafi'i dengan mengambil kira realiti hidup setempat setakat yang dibenarkan oleh instrumen qiyas sepertimana yang sentiasa ditegaskan oleh Imam Syafi'i sendiri. Sepatah kata terakhir: Sesungguhnya kebijaksanaan itu terletak pada kemahiran merealisasikan idealisme walau setinggi mana sekalipun dalam realiti walau seburuk mana sekalipun. Kata Umar al-Khayam dalam Ruba'iyāt nya : "Semalam sudah berlalu, besok masih dalam cita-cita. Realitinya hari ini". 
Jurnal Fiqh: No. 4 (2007) 1-38 